\title{
RECONCILING LEARNING AND TEACHING STYLES IN SCIENCE, TECHNOLOGY ENGINEERING AND MATHEMATICS DISCIPLINES THROUGH COGENERATIVE DIALOGUES
}

\author{
Nelson Nunez Rodriguez \\ Hostos Community College of CUNY, New York, USA \\ E-mail: nnrodriguez@hostos.cuny.edu
}

\begin{abstract}
The use of cogenerative dialogues in Science disciplines is a pedagogical approach bringing together the plethora of academic and cultural backgrounds of current community college students. Specifically, this project illustrates the effects of integrating cogens in a community college chemistry class for science majors. Cogenerative dialogues were implemented in a Hostos Community College spring 2011 chemistry class as follows: some students discussed class issues with the professor in an informal setting once a week. An integrative assignment connecting typical foods from different countries was used as a framework to reinforce the learning process and to unravel content misunderstanding. The project outcomes transcended spring 2011 semester. A new book has been adopted in the class as a result of the dialogue. Oral presentations, the use of masteringchemistry.com and a forum to create exam questions have been implemented. Office hours are now used to both develop specific class problems and to dialogue with students about learning styles. Overall, cogenerative dialogues have opened a venue to facilitate the learning of difficult science concepts while building an atmosphere of acceptance, respect, and collegiality between instructor and the students.
\end{abstract}

Key words: cogenerative dialogues, student diversity, college STEM teaching and learning.

\section{Introduction}

The plethora of academic and cultural backgrounds of today's community college students represents an enriched arena to foster learning from different angles (Olson, Labov, 2012). On one hand, the disparity of student academic backgrounds continues to be a challenge for instructors. On the other hand, their cultural backgrounds and personal literacy skills are springboards to develop academic literacy. Resilient pedagogues should be able to explore different student ways of knowing as a fertile arena to develop alternative ways of learning. Science, Technology, Engineering and Mathematics (STEM) community college students are part of this scenario (Labov, 2012). Indeed, they represent a pivotal population to STEM field. Twenty-five percent of students graduating with a bachelor degree in science in the United States began their education at community colleges. The use of cogenerative dialogues (hereafter cogens) in STEM disciplines at community college can be a pedagogical approach to bring together above-mentioned scenarios. Cogens validate learner voices as a learning foundation. This dialogue also reinforces learner beliefs about their potential success and infuses a sense of belonging to the academic system, which is essential in term of retaining minority students pursuing college education (Hansen, 1994; Patton, 2006; Olson, Labov, 2012). 
Nelson NUNEZ RODRIGUEZ. Reconciling Learning and Teaching Styles in Science, Technology Engineering and Mathematics Disciplines through Cogenerative Dialogues

LATION

OF EDUCATION

IN THE $21^{\text {st }}$ CENTURY

Volume 52, 2013

106

Cogens are discussions that take place over shared experiences involving teaching and learning, and can involve students, instructors, researchers, and sometimes administrators (Tobin and Roth, 2006). It emerged from the idea of students having a voice in how to "better teach them" (Tobin, 2008). Cogens, therefore, are social fields in which new culture is produced (Tobin and Roth, 2006). Such culture, for example, is oriented toward the production of solidarity and shared goals associated with teaching and learning. This interaction proposes a less authoritarian, more democratic relationship in which students have increased choice and authority (MorenoLopez, 2005). This dialogue also deepens understandings about the complexities of urban postsecondary classrooms, including teaching and learning expectations, and how such complexities mediate students' academic achievement and attainment. Cogens provide an arena to address these issues by capitalizing on the learners' voices in the pedagogical process. Cogens have been found to unravel content misunderstandings and acknowledge students' varied heritages and cultural values. Cogens facilitate the learning process by nurturing a safe atmosphere in which to learn, as well. This framework helps instructors to learn from students rather than to make assumption about students' dispositions to learn at the early stages of the course. Cogens also bring a controlled unpredictability, offering different angles to improve learning.

\section{Problem of Research}

The purpose of this study is to investigate the effect of integrating cogens in a chemistry class for science majors at the community college level. This project aimed to improve the quality of learning and teaching in STEM courses. Community colleges are playing an essential role in the current landscape of the United States higher education system. On one hand, for many minority students, it is the only access to higher education. On the other hand, they have to overcome linguistic and academic under preparedness to meet the college work expectations (Labov, 2012). In this regard, many strategies are going on across the United States trying to increase and retain the amount of minority students into STEM field (Gottesman, Hoskins, 2013). In this regard, personal literacy, as many of them have meaningful life experiences as immigrant and single parent, can be used as a foundation to develop academy literacy. I hypothesized that the use of cogenerative dialogue is an effective vehicle to explore students' learning styles and to capitalize their personal and social experiences in the pedagogical process. This initiative included faculty from several City University of New York institutions. A cogenerative dialogue took place in a spring 2011 chemistry class as part of the Institutional Research Board approved-Teaching Research Project Value of the use of cogenerative dialogues in STEM Classes.

\section{Methodology of Research}

\section{Sample}

Cogens were implemented in a general chemistry class for science and engineering majors at Hostos Community College of City University of New York. This college is located in the South Bronx, New York. This is one of the poorest districts of the country. Our institution serves the poorest and least prepared student population in our university system. Eighty-three $\%$ of Hostos students belong to Hispanic and African American populations. Over 70\% of Hostos students are from households with less than $\$ 30,000$ annual income, compared to $63 \%$ for all CUNY community colleges, which is critical in a high cost living city as New York. Almost $60 \%$ of our students are first-generation college students, compared to $48 \%$ for all CUNY community colleges. Finally, $38 \%$ of Hostos students support children, in contrast to $16 \%$ for all CUNY community colleges. 
Students taking Chemistry for Science majors are part of this reality. They are required to be taking at least pre Calculus and a college level English class by the time they take chemistry. Many of them have developed college behavior; nevertheless, improving their study skill and the ability to apply mathematics concepts to science classes remain as daunting challenges for them. A total of eight students, from a 25 student class, were initially involved in the dialogue with five students attending all sessions. I selected them during the second week considering their grade point average, their results in an initial formative assessment and their engagement in the class. Based on these criteria, three students had strong background. The other five had moderate to weak background.

\section{Cogens Structure}

Cogens were implemented in a spring 2011 Chemistry class as follows: eight students from a 25 student-class discussed the class issues with the professor in an informal setting. This conversation happened during the office hour immediately after class. Intending to improve their learning, this dialogue took place once a week. See Table 1 with details.

Table 1. Amount of students involved in the cogenerative dialogues.

\begin{tabular}{lllll}
\hline $\begin{array}{l}\text { Number of Cogens } \\
\text { Dialogues }\end{array}$ & Term weeks & $\begin{array}{l}\text { Amount of stu- } \\
\text { dents involved in } \\
\text { the dialogue }\end{array}$ & $\begin{array}{l}\text { Total Amount of } \\
\text { students in the } \\
\text { class }\end{array}$ & $\begin{array}{l}\text { Percent of total } \\
\text { amount students } \\
\text { attending the } \\
\text { dialogue }\end{array}$ \\
\hline 9 & $\begin{array}{llll}\text { From week } 3 \text { to } \\
\text { week 12 }\end{array}$ & $\begin{array}{l}8 \text { (5 attended all } \\
\text { sessions) }\end{array}$ & $\begin{array}{l}25 \text { (21 students } \\
\text { completed the } \\
\text { course })\end{array}$ & $\begin{array}{l}30.8 \% \\
24 \% \text { (attended all } \\
\text { sessions) }\end{array}$ \\
\hline
\end{tabular}

\section{Data Collection and Teaching Intervention}

The cogen's structure also included taping classes and cogens conversations, pointing out class incidents related to content comprehension difficulties and discussing its different perspectives. No more than three issues were addressed in each approximately 20 minute-cogens conversation. Class discussions based on an integrative assignment connecting typical foods from different countries usually followed up cogens. This framework was intended to reinforce the learning process and to unravel misunderstanding of content. A safe atmosphere embraced the learning process, as typical food recipes and preparations were discussed. For instance, the composition and recipe of typical hispanic food Mofongo was discussed, as this dish is very popular in our student population. This practice validated student heritage and culture values based on foods. The following chemistry topics were interwoven with the food assignments: mixtures, measurements, naming, percent composition of compounds, chemical reaction in aqueous solutions, acids and bases, thermochemistry, solutions and solution concentrations. For example, if cogens unraveled difficulties understanding mixtures, I began the class asking students to share their food assignment preparation. I asked specific questions compelling them to apply the concept in their real life example; subsequently, I revisited the content idea but always revolving around example brought by students.

Cogens interventions also prompted the implementation of student oral presentation in the classroom as a way to enhance content understanding. Every week, one student presented a topic relating real-life issues with the class content. Presenters were evaluated by class peers who used rubrics created for this initiative (Table 2 and 3). Embedding writing and oral presentation has a demonstrated effectiveness developing student critical thinking (Bean, 1996). I developed 
Nelson NUNEZ RODRIGUEZ. Reconciling Learning and Teaching Styles in Science, Technology Engineering and Mathematics Disciplines through Cogenerative Dialogues

OF EDUCA

PROBLEMS

IN THE $21^{\text {st }}$ CENTURY Volume 52, 2013

108

collaboration with a public speaking professor interested to blend content areas with public speaking classes. This initiative was devised as follows: public speaking students participated in two joined sessions coaching science students with their oral presentation. A public speaking professor, with strong experience in theater direction, shared speech tips with science students during two other sessions. During the final presentation, public speaking students anonymously evaluated science students. The public speaking professor, finally, assessed how his students were able to assess science student presentations.

Table 2. Criteria used by students to evaluate their peer presentations.

\begin{tabular}{ll}
\hline 15 pts. & Meet all of the following criteria: \\
& Content is clearly presented \\
& Allowing for questions and answers \\
& Generating discussion if relevant \\
& Presentation lasts for 5minutes \\
& Including relevant information from other materials \\
& Starting with an introduction and ends with a conclusion \\
\hline 9 pts. & Meet five of the criteria listed above \\
\hline 6 pt. & Meet four of the criteria listed above \\
\hline 3 pts. & Meet less than four of the criteria listed above \\
\hline
\end{tabular}

Table 3. Additional Criteria used to evaluate student presentation.

\begin{tabular}{ll}
\hline Answer Yes or Not & Yes, explain \\
\hline Remembering: can the student recall or remember the information? & Not, explain \\
Applying: can the student use the information in a new way? & \\
Analyzing: can the student distinguish between the different parts? & \\
Creating: can the student create a new product or point of view? &
\end{tabular}

\section{Results of Research}

\section{Students' Feedback during Cogens and Subsequently Implemented Ideas Based on the Dialogue}

Class Materials: Students pointed out difficulties understanding the course assigned textbook and lab manual. Clearly, this was based on the fact that English is not the native language for many of our student population. The content specific language, as it relates to how English language mechanics are used in the science texts, represents additional challenges. With their lab manual, students were required to create a flow chart for each lab experience. Despite language challenges, students persisted, and documented that the professors' explanation before lab experience was essential to their success. The same applied for problem solving strategies on the blackboard during class time. Students emphasized the need for having clear algorithms developed on the board by the instructor to improve learning. Overall, the professor changed the textbook because of the challenges that were brought to light by the students during cogens. Formerly, students used the book Chemistry (Chang, 2010). In the subsequent semester a new book was tested. Chemistry, a molecular approach (Tro, 2011) was piloted and implemented as required textbook. It also included the use of masteringchemistry.com, an online platform providing an interacting homework experience (Figures 1 and 2). Students pointed out during cogens the need of having feedback on the homework. Masteringchemistry. 
Nelson NUNEZ RODRIGUEZ. Reconciling Learning and Teaching Styles in Science, Technology Engineering and Mathematics Disciplines through Cogenerative Dialogues

com provides students with prompts that help them solve problems. The instructor can decide if online exercises warrant point deductions or not. Currently, students can use prompts without

PROBLEMS OF EDUCATION IN THE $21^{\text {st }}$ CENTURY Volume 52, 2013 deduction on the homework and with point deduction during the online quiz. No access to the prompts is allowed during the individual online exam.

\section{MasteringChemistry ${ }^{\circ}$}

Make Learning Part of the Grade ${ }^{\circledR}$
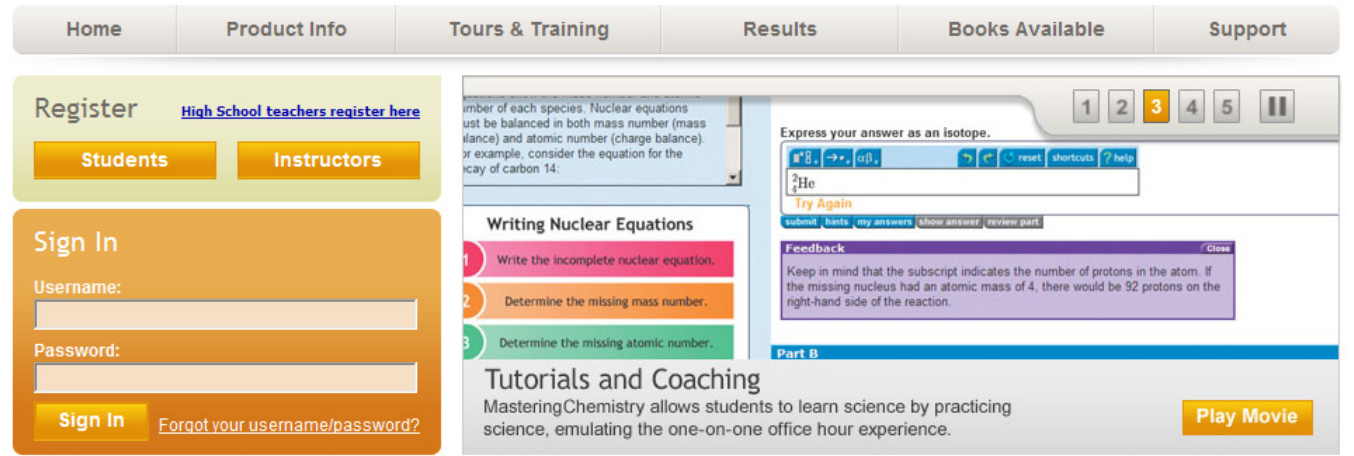

\section{Figure 1: Masteringchemistry.com website (from Pearson publisher) for chem- istry students.}

From “Mr. Robinsons's General Chemistry pages” by D. Robinson, 2013, http://www.dlrgenchem.com, retrieved by March 11, 2013.

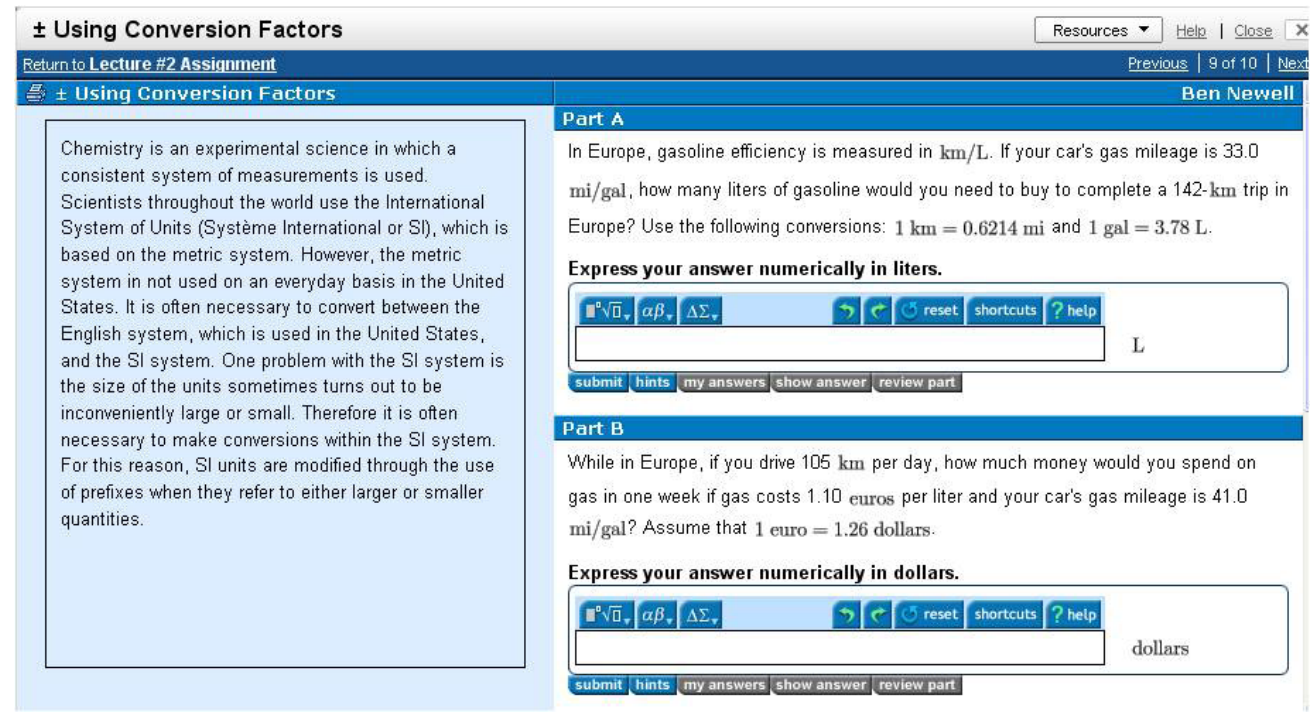

\section{Figure 2: Chemistry problem in masteringchemistry.com (from Pearson pub- lisher) for chemistry students.}

From Getting started with chemistry, by M.W. Stoltzfus, 2011, http://drfus.com/chem-1210/gettingstarted-with-mastering-chemistry. Retrieved March 11, 2013. 
Nelson NUNEZ RODRIGUEZ. Reconciling Learning and Teaching Styles in Science, Technology Engineering and Mathematics Disciplines through Cogenerative Dialogues

OF EDUCATION

IN THE $21^{\text {st }}$ CENTURY

Volume 52, 2013

\section{Learning Habits}

Student grades and skill development along the term for all students and for students involved in the cogens are shown in Tables 4 and 5. Three students involved in the cogens did not begin performing well. The bonding created by interacting with other students during cogens developed and strengthened individual student study habits and built confidence related to student potential success, as they organically created a study group that included students involved in the cogens experience.

Table 4. Grade progression for Cogens and all students. Maximum grade $=100 \%$.

\begin{tabular}{lll}
\hline & Total Students $\mathrm{n}=\mathbf{2 5}$ & Cogens Students $\mathrm{n}=\mathbf{5}$ \\
\hline Exam I: & $77.84 \pm 17.5$ & $72.25 \pm 20.61$ \\
Exam II: & $89.74 \pm 20.74$ & $92.97 \pm 16.64$ \\
Exam III: & $75.05 \pm 24.34$ & $72.83 \pm 14.25$ \\
Exam IV: & $70.6 \pm 22.1$ & $70.3 \pm 15.8$ \\
Final Exam: & $79.2 \pm 14.6$ & $80.8 \pm 12.3$ \\
\hline
\end{tabular}

Table 5. Skill progression for Cogens and all students. More than $70 \%$ out of $100 \%$ in the grade associated to exam questions evaluating specific skill was considered a satisfactory level of skill acquisition. Less than $70 \%$ out of $100 \%$ was considered unsatisfactory level. Results are shown as frequency of students attaining the specific skill.

\begin{tabular}{|c|c|c|c|c|c|c|c|c|}
\hline $\begin{array}{l}\mathrm{N} \text { (amount of } \\
\text { students) }\end{array}$ & $\begin{array}{l}\text { Total } \\
n=22\end{array}$ & $\begin{array}{l}\text { Cogens } \\
n=6\end{array}$ & Total $n=19$ & $\begin{array}{l}\text { Cogens } \\
n=5\end{array}$ & Total $n=17$ & $\begin{array}{l}\text { Cogens } \\
n=5\end{array}$ & $\begin{array}{l}\text { Total } \\
\mathrm{n}=21\end{array}$ & $\begin{array}{l}\text { Cogens } \\
n=5\end{array}$ \\
\hline Skill/Exam & $\begin{array}{l}\text { Exam } \\
\|\end{array}$ & $\begin{array}{l}\text { Exam } \\
\|\end{array}$ & Exam III & Exam III & Exam IV & Exam IV & $\begin{array}{l}\text { Final } \\
\text { Exam }\end{array}$ & $\begin{array}{l}\text { Final } \\
\text { Exam }\end{array}$ \\
\hline $\begin{array}{l}\text { Difficulty } \\
\text { Level: Easy } \\
\text { Competency: } \\
\text { Problem Solving }\end{array}$ & $\begin{array}{l}70 \%: \\
14 \text { of } 19\end{array}$ & $\begin{array}{l}70 \%: \\
5 \text { of } 6\end{array}$ & $\begin{array}{l}70 \%: \\
14 \text { of } 19\end{array}$ & $\begin{array}{l}70 \%: \\
4 \text { of } 5\end{array}$ & $\begin{array}{l}70 \%: \\
10 \text { of } 17\end{array}$ & $\begin{array}{l}70 \%: \\
4 \text { of } 5\end{array}$ & $\begin{array}{l}70 \% \\
17 \text { of } 21\end{array}$ & $\begin{array}{l}70 \% \\
5 \text { of } 5\end{array}$ \\
\hline $\begin{array}{l}\text { Difficulty } \\
\text { Level: Medium } \\
\text { Competency: } \\
\text { Problem Solving }\end{array}$ & $\begin{array}{l}70 \%: \\
17 \text { of } 22\end{array}$ & $\begin{array}{l}70 \%: \\
5 \text { of } 6\end{array}$ & $\begin{array}{l}70 \%: \\
14 \text { of } 19\end{array}$ & $\begin{array}{l}70 \%: \\
4 \text { of } 5\end{array}$ & $\begin{array}{l}70 \%: \\
12 \text { of } 17\end{array}$ & $\begin{array}{l}70 \%: \\
3 \text { of } 5\end{array}$ & $\begin{array}{l}70 \%: \\
14 \text { of } 21\end{array}$ & $\begin{array}{l}70 \%: \\
3 \text { of } 5\end{array}$ \\
\hline $\begin{array}{l}\text { Difficulty } \\
\text { Level: High } \\
\text { Competency: } \\
\text { Problem Solving }\end{array}$ & $\begin{array}{l}70 \%: \\
11 \text { of } 22\end{array}$ & $\begin{array}{l}70 \%: \\
4 \text { of } 6\end{array}$ & $\begin{array}{l}70 \%: \\
5 \text { of } 19\end{array}$ & $\begin{array}{l}70 \%: \\
1 \text { of } 5\end{array}$ & $\begin{array}{l}70 \%: \\
11 \text { of } 17\end{array}$ & $\begin{array}{l}70 \%: \\
3 \text { of } 5\end{array}$ & $\begin{array}{l}70 \% \text { : } \\
13 \text { of } 21\end{array}$ & $\begin{array}{l}70 \%: \\
3 \text { of } 5\end{array}$ \\
\hline
\end{tabular}

The dialogue reinforced the need of building teams to study. It built confidence and created advantages of using native languages as vehicles to improve content understanding. In study groups, students switched constantly to their native language to more easily express their ideas. 


\section{Giving Authority to the Learner Voices}

As a result of cogens experience, an oral class presentation was added to course requirements in the subsequent semester. Every week, one student presented a topic relating real-life issues with the class content. For example, chemical components used to develop smart devices and all the social issues surrounding its extraction from Congo mines, was a topic discussed. This active learning process led to a public speaking component in the classroom, as many students who knew the material failed to present it clearly. Fifteen students out of 23 ones agreed that this class component helped them to understand better the material and improved their engagement in the classroom. Eighteen out of 23 students supported the idea that connecting real life issues with the class content as a way to facilitated course material understanding.

Eight out of 25 students delivered oral presentations every semester after this initial experience. This exercise not only brings relevance to the class content but also familiarizes students with the use of rubrics and with an evaluation system. In this regard, a Blackboard forum has been implemented where students could build on their exams by suggesting questions and justifying why these questions are essential to assess specific content. This practice harmonizes the ultimate contradiction between the learner and the instructor: the assessment process. The online forum also develops a sense of students as creator in the pedagogical process rather than follower of the rules. Twelve out of 25 of the students were involved in this process by posting 109 questions during the subsequent semester. Random questions posted by students were part of the class exam. Students received points for good questions even if these questions were not part of the exam.

\section{Discussion}

Attuning teaching styles by listening to students was an important outcome from this project. It sheds light on the importance of acknowledging student learning styles such as digital ones and their first language opportunities and challenges. Project outcomes, indeed, transcended the project period. Chemistry, a molecular approach (Tro, 2011) was adopted as the class book from spring 2012 based on spring 2011 cogens outcomes and fall 2012 book piloted experience. Oral presentations, the use of masteringchemistry.com, a forum to create exam questions and collaboration with a public speaking professor have been integrated into the course. Cogens dialogue also opened a new dimension during office hours. Besides using it to develop specific class problems, it is currently an opportunity to dialogue about learning styles, why specific content is more difficult and why some content bottlenecks are challenging for the students.

Cogens also bring a controlled unpredictability atmosphere in the classroom offering different ways of thinking to improve student learning. Using student personal literacy ideas to discuss class content reconciles natural contradictions between instructors and students regarding the learning process. Discussing learning challenges during office hour brings more coherence to the class content and establishes a learning continuum beyond class period.

Intertwining class content with foods from different countries relies heavily on students' native languages since certain foods and ingredients usually have no translation into English. This practice allow to understand aspects of their individual cultures using class content, and ultimately opens a route for constantly appraising life issues with a science perspective. In this regard, liberal arts and science education also represents an opening to the world of ideas and a culture of appreciation of other points of view for our students, as well. Indeed, merging student languaging into the learning process adds a reconciling value to the pedagogy in minority serving-urban institutions. Cogens dialogue fostered the implementation of another experience 
Nelson NUNEZ RODRIGUEZ. Reconciling Learning and Teaching Styles in Science, Technology Engineering and Mathematics Disciplines through Cogenerative Dialogues

PROBLEMS

OF EDUCATION

IN THE $21^{\text {st }}$ CENTURY Volume 52, 2013

112

considering linguistic diversity. It included a unique warm-up exercise that met global learner processing needs (Dunn, Honigsfeld, Shea, 2009). Some lessons begin by inviting everyone to translate a key word of the new topic into a language of their choice. Those who process new and/or difficult information better globally than through analytic strategies had a chance to experience a personal connection to the concept and, therefore, began to develop an understanding of why the topic is relevant. Ultimately, chemistry language is new for all of them. This connects social, personal, and linguistic diversity into STEM disciplines. Exposing our genuine differences in how we interpret and experience realities, how and where we are situated and the social identities that shape our thinking is important to understand both how our students learn and the complex role of instructors in urban urban class settings (Stith, Roth, 2010). It also allows faculty to reflect on how using both their personal and students' experiences helps to develop content understanding and cognitive skills. In the long run, this mutual understanding of identities opens a social justice environment in the classroom regardless specific disciplines (Wlodkowski, Ginsberg, 1995; Roth, Tobin, Elmensky, Carambo, Mcknight, Beer, 2004; Emdin, 2011) which means connectedness between academic environment and different cultures, but more important, a crucial action for retaining historically underrepresented populations in higher education. Cogens experience outcomes shed lights on our student possibilities to success in the higher education system and also to develop mechanisms to use any knowledge level they are bringing to the classroom as academic literacy foundation. This experience demonstrated that personal literacy, including life experiences such as maternity, immigration, opening to another culture and country habits are assesses for higher education access. Bilingualism is also another foundation opening creative routes for developing learning and teaching styles. Student first encounter with higher education shall reinforce all these aspects. By being a bridge between student personal literacy and the academic expected, community college education emphasizes learning as a lifetime experience. This definitely improves student self-esteem, tolerance for obstacle, and more important sense of accomplishment and belonging to the higher education system. This is critical for underserved population in the higher education system in the United States as the nationwide lack of student retention in the system is connected with these aspects (Hausmann, Schofield, Woods, 2007; Labov, 2012).

\section{Conclusions}

Overall, cogens have opened a venue to facilitate learning processing of difficult science concepts while building an atmosphere of acceptance, respect, and collegiality between instructor and the students. Choosing a new book considering student learning styles, opening a forum to create exam questions together and implementing oral presentations not only foster student ownership of their educational process, but more important, develop creative thinking instead of a following the rule atmosphere. These results also expand science-teaching perspective in urban community college institution. It shows the need of using student literacy levels as an avenue to promoting active learning. Cogens experience demonstrated the need to exploit students' social and cultural capital in the learning process. In this regard, it is recommended to integrate personal and cultural experiences into science class assignments such as food preparation from different cultures. The emphasis placed on specific life aspects such as hair care, use of jewellery, skin care, by different ethnic groups may be used to develop concrete assignments that foster a climate of diversity respect and acceptance and also reinforce lifetime learning habits as it reverberates on student daily life. In this regard, the evaluation of YouTube videos and other online resources related to class content appears as an interesting avenue to both foster a culture of knowledge evaluation and validate digital learning styles. In this information based-era, students must be able to sift thoughtfully through increasing amount of information evaluating reliable resources among the vast collection of surface facts, misinformation and 
lies. Many of them use open access online resources to study. This tool can be used to flip the classroom as students may be required to evaluate it before coming to classes. The instructor

PROBLEMS OF EDUCATION IN THE $21^{\text {st }}$ CENTURY Volume 52, 2013 can begin the session asking for mistakes and accurate facts found in assigned online resources. Overall, this work shows the effectiveness of using cogenerative dialogues as an embracing pedagogy that takes advantage of the complex and diverse academic, social, linguistic and ethnical backgrounds that students bring to today's urban institutions.

\section{References}

Bean , J. C. (1996). Engaging Ideas: The professor's guide to integrating writing, critical thinking, and active learning in the classroom. San Francisco, California: Jossey-Bass.

Chang, R. (2010). Chemistry (11 ${ }^{\text {th }}$ Ed.). New York, NY: McGraw Hill.

Dunn, R., Honigsfeld, A., Shea, D. L. (2009). Impact of learning-style instructional strategies on students' achievement and attitudes: Perceptions of educators in diverse institutions. The Clearing House, February-March, pp. 135-140.

Emdin, C. (2011). Citizenship and social justice in urban science education. International Journal of Qualitative Studies in Education (QSE), 24 (3), 285-301.

Gottesman, A. J., Hoskins, S. A. (2013). CREATE Cornerstone: Introduction to Scientific Thinking, a New Course for STEM-Interested Freshmen, Demystifies Scientific Thinking through Analysis of Scientific Literature. CBE-Life Sciences Education, 12, 59-72.

Hansen, L. D. (1994). Talking about leaving: Factors contributing to high attrition rates among science, mathematics, and engineering undergraduate majors. Final report to the Alfred P. Sloan Foundation on an ethnographic inquiry at seven institutions. Boulder, CO: University of Colorado, Ethnography and Assessment Research, Bureau of Sociological Research (Seymour, E., Hewitt, N.M.). Journal of Chemical Education, 71 (12), A310.

Hausmann, L. R. M., Schofield, J. W., Woods, R. L. (2007). Sense of Belonging as a Predictor of Intentions to Persist Among African American and White First-Year College Students. Research in Higher Education, 48 (7).

Labov, J. (2012). Changing and evolving relationships between two- and four-year colleges and universities: They're not your parent's community colleges anymore. CBE-Life Sciences Education, 11, 121128.

Moreno-Lopez, I. (2005). Sharing power with students: The critical language classroom. Radical Pedagogy, 7, 2.

Olson, S., Labov, J. B. (2012). Community colleges in the evolving STEM education landscape: Summary of a summit. The National Academies Press, Washington, DC, USA.

Patton, M. (2006). Teaching by choice: Cultivating exemplary community college STEM faculty. The American Association of Community College-The Community College Press. A Division of the American Association of Community Colleges, Washington, DC, USA.

Roth, W., Tobin, K., Elmensky, R., Carambo, C., McKnight, Y., Beer, J. (2004.) Re/Making identities in the praxis of urban schooling: A cultural historical perspective. Mind, Culture \& Activity, 11 (1), 48-69.

Stith, I., Wolff-Michael, R. (2010). Teaching as mediation: The cogenerative dialogue and ethical understandings. Teaching \& Teacher Education, 26 (2), 363-370.

Tobin, K., Roth, W. M. (2006). Teaching to learn: A view from the field. Rotterdam, The Netherlands: Sense Publishing.

Tobin, K. (2008). Fostering science learning in diverse urban settings. American Institute of Physics Conference Proceedings, 1064, pp 50-52.

Tro, N. (2011). Chemistry, a molecular approach ( $2^{\text {th }}$ Ed.) New York, NY: Pearson.

Wlodkowski, R. J., Ginsberg, M. B. (1995). Diversity \& motivation: Culturally responsive teaching. San Francisco, CA: Jossey-Bass Social and Behavioral Science Series. 
Nelson NUNEZ RODRIGUEZ. Reconciling Learning and Teaching Styles in Science, Technology Engineering and Mathematics Disciplines through Cogenerative Dialogues

PROBLEMS

OF EDUCATION

IN THE $21^{\text {st }}$ CENTURY

Volume 52, 2013

Advised by Muammer Calik, Karadeniz Technical University, Turkey

Received: February 08, 2013

Accepted: March 19, 2013

Nelson Nunez Rodriguez PhD., Associate Professor, Hostos Community College of CUNY, 500 Grand Concourse, Room A507, Bronx, 10451 New York, USA.

E-mail: nnrodriguez@hostos.cuny.edu

Website: http://www.hostos.cuny.edu/oaa/nas/Facultylnfo.htm 